\title{
Humour and love: the origination of clown therapy
}

\section{Patch Adams}

\section{Compassion, joy, love, and humour are essential to build healthy and peaceful societies}

$\mathrm{T}$ he events of terror in the United States on 11 September 2001 have provoked many reactions and the traditional revenge/fear action. The casual, quick acceptance of this response globally, instead of outrage over more senseless carnage, is symptomatic, in medical jargon, of a massive malignant cancer in human society. Also symptomatic is that, on the same day, over 30000 children died of starvation and there was no noise heard.

As I explore the health of the human society, with the same tender, thoughtful compassion I have explored individual patients, I find the "patient" in critical condition, needing global universal attention. Why do we revere our diversions, and neglect our collective health? We live in a country where athletes and actresses are multimillionaires. Though school teachers are second only to mothers in supporting a healthy human society, in the US, $60 \%$ have to hold second jobs to support a family.

Mechanisms need to be found to help midwife a human society that never needs war again; where all are cared for (and all of nature too), and life is a celebration. At this point in human history these goals can no longer be considered idealistic or naive. They are thoughtful imperatives if we want to get humans off the endangered species list.

I know, after September 11th, everywhere I travelled I heard the nation echoing our president's immediate call to war. I started to ask my audiences if any of them had wondered what "love strategy" could effectively respond to terror? I've never heard any nation or people discuss a love strategy in the face of violence. We have to be the pioneers. First,

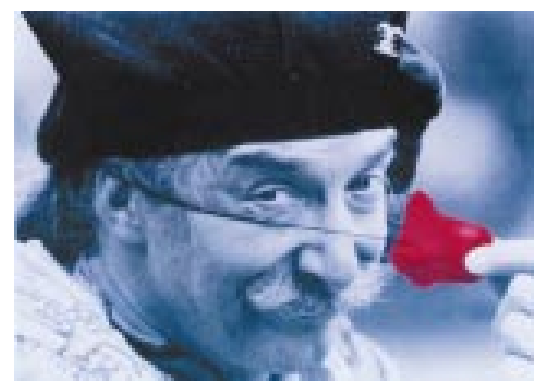

we declare the intention to be peaceful and loving and, being present in all situations, observe how we perform our intentions. We notice the consequences of each performance, and if it puts our intentions forward, we add that strategy to the ongoing performance of our public selves.

I know, as a pacifist, that I never see more violence as a strategy. Strategy implies thoughtful consideration. Violence mostly feels visceral. I try to imagine generals giving up on the "war room", heading instead for the "love and humour" room to strategise an end to violence.

I have asked myself often since then, what is my love strategy? I know, at my deepest levels, that deciding in my teens to be universally and publicly friendly and a celebrant of life, was the strongest strategic step I've ever taken for love. Surely love and humour will never defeat violence and injustice, for they never exert power-over. But they are capable of irresistible transformation. We must practise compassion and generosity in ways that seduce those drunk on personal power and greed and lovers of power-over and money to consciously choose compassion and generosity.

So how does that seduction work? The strongest transforming mechanism I know is to give people the opportunity to help others who suffer. Over time, many feel a powerful inner glow that drives them to make helping part of their life. Add learning about the problems and solutions (you can find a rich bibliography at www.patchadams.org) and you're primed for creative leadership.

It is inherent in these concerns that clowning needs to be a context, not a therapy. It is funny to this clown to say "clown therapy". Of course it is therapeutic! If a love strategy existed in our society, no one would need clown therapy. But modern hospitals and medical practices around the world scream out to reconnect the delivery of care to compassion, joy, love, and humour. For over 30 years I've heard thousands of medical students, doctors, nurses, and patients weep for love's absence in their medical setting. The lost "love strategy" is the single strongest cause of the dramatic and growing shortage of nurses.

There is never a concern for profit or solitary power in the love strategy. Throughout history, I think the love strategy has been practised by women, often invisibly. Even though most of the service professions are notoriously low paying, women have historically done the majority of them, freely acting out their love strategy. Now, greed and power-over have so infected our culture, it is getting harder for the love strategy to prevail, even in health care and education.

It used to be hard for love and fun to get in the door at hospitals. Mostly, volunteers became the carriers, glad to trade in love and fun because the personal rewards were so powerful. Hospital clowns have become the locus of humour and love, and what they do has been classified a therapy. But this greatly shortchanges us! We don't need a puny love-and-fun therapy! We need love and fun as a context; the very stage on which we act out the dramas of health and life and death. When love and fun are the context, every hospital employee will be loving, joyful, tender, and fun.

If we allow our strategic love to remain a therapy, we're implying that there are times it isn't necessary. But if we commit to growing love as the context, we are called to continually create an atmosphere of joy, love, and laughter. There are so many simple ways to do it: I often feel like the clown costume is a trick to get love really close to patients.

As soon as we see the health value of a context that is joyous, loving, and funny with the dying patient and the person in the street, we can decide to contribute to a context of love and fun every day. This makes our communities healthier, and helps to build a peaceful and loving society. This one decision and the gestures and connections which are sparked by it can bring sweet meaning to anyone's life daily.

I have done vast numbers of clowning experiments in public all over the world every day for 38 years now, and have found friendliness and celebrating life to be the heavy artillery of the love strategy. Add generosity and one can taste the revolution of care. It easily calms stressful situations and comforts countless griefs. My experiments have shown me that public love and fun are so important that I have chosen to wear only clown clothes publicly every day for over 20 years, to do my part. It enhances the richness of my life and has made the whole journey enchanting.

By the time I entered medical school in 1967, I had taken the power of clowning to heart, and was trying to bring humour, love, and joy to every situation. When I began to see patients (of any age) I insisted on being funny with all of them, even the profoundly ill. What was 
less obvious, was that it was just as important to be fun (loving and joyful) with the staff and visitors to the hospital. It was bringing humour to all of it that was the point, clearly knowing it was also wonderful for my own health. I was a stranger to that burnout which is endemic in modern hospitals.

I know the clowning was mostly carried by smiling eyes and mouth, an impromptu song, and a patient, listening attention. Over time I've added props and become a character. I've been the "guy with the fish" for many hundreds of hours. When we had our own hospital the humour was much more outrageous and integral to the life in the community; even its social glue.

I began to lead group clown trips in 1985. I never required any clowning experience of the participants. I simply asked people to wear clown clothes and to spread love and fun. I knew performing would come with time. I wanted people to see that anyone could do it. The idea slowly grows of taking this loving, fun context to many diverse settings from death rows in prisons, to orphanages, nursing homes, refugee camps, even war zones. It transforms the toughest places. I took clowns to refugee camps in Kosovo in 1997. The camp elders came to us after our first day to say that it was the first time they saw children playing in the camp, or couples holding hands; love and humour breathed life back into these suffering people.

I applaud hospitals for opening themselves to staff clown positions, and to the clowns who take on this healing work. And I want to put in an encouragement for each person, professional clown or not, to imagine that what they do each day can be a potent part of creating a context of love and fun. Each one of us can be an instrument of the love strategy! If you need ideas, I wrote my second book, House Calls, to help people learn to make fun, compassionate, creative housecalls-in the hospital or out-on all sorts of people.

The hospital clowns have spent most of their time in paediatrics, and I have from the beginning encouraged clowns to go to the adult wards as well. I actually prefer clowning for adults because they have a much broader life experience. I can only hope that when people see the clear value of bringing love and humour into a hospital setting they will connect with the need to do it everywhere. Maybe a next step is to get clowns (fools, jesters) back into the political arena next to the leadership, both political and corporate. I cannot see George Bush and his cronies so flagrantly serving multinational corporations if the inner circles were held accountable by truth telling fools.

When clowning (or humour, love, joy) is thought of as a therapy and the clown as a specialist who can do it, others can think that love, humour, and joy are covered and they don't have to help create that context. So the staff and visitors don't see that they are also creators of this context. In the past, when having a "good bedside manner" was high accolade to nurse or doctor, it had nothing to do with their scientific expertise. In truth, it was a comment on their ability to bring love, joy, and humour to the bedside.

So I call all people to support any clown work in hospitals; for their job is to be the presence of something precious and necessary for all who suffer and all who do not. I hope that all who see the potency in action will be stimulated to make themselves an instrument of joy, love, and humour.

Postgrad Med J 2002;78:447-448

Correspondence to: Dr P Adams, Gesundheit Institute, 6855 Washington Blvd, Arlington, VA 22213, USA; Heidi@SillyStuff.org
Recommendations for doctors

- Study the infinite literature on love and loving. You will find a clear call for more love everywhere-poetry: Neruda's Love Sonnets, May Swenson's Love Poems; psychology: Erich Fromm's The Art of Loving; medicine: Dean Ornish's Love and Survival.

- Do five years of field work with people, everywhere you go, being loving with them and receiving any love offered. Find your loving selves.

- Add humour to your practice; this is easiest when you are already being compassionate. If a patient perceives you love them, they will forgive (even delight in) any humorous experiences you share. You can always cite references about the healing effects of humour.

- Be a keen and tickled observer of people.

- Choose to put humour in the public space with a smile on the face, a twinkle in the eyes, and a willingness to greet each person.

- Practise with various props. Farts are the only thing I've found to be universally funny in all countries. There are many little devices on the market, even a glorious remote control farter.

- Society gives full permission to laugh out loud, always assuming good reasons caused it. So practise public laughing.

- Study videos of funny people and steal bits from each. There is a gold mine there.

- Study books on the history of costumes. Have a few made to fit you and use them regularly.

- Declare a personal intention to be an instrument for peace, justice and care. Then take action!

- or anyone who has seen Robin Williams in Patch Adams this book is essential reading. The issues raised in the film about the relationships between doctors and their patients are explored in greater detail. The book provides a surprising analysis of the research base on which Patch's approach to clinical care is based. The confidence with which he approaches patients is refreshing, especially in a country where malpractice cover is so essential. However, that very basic element of clinical practice has never formed part of Patch's approach. He has survived without it and indeed thrived. The need to put humanity and humour back into clinical practice is the driving force behind Patch's clinical work and is also the basis of his message to other clinicians and patients across the world

Although you may not always agree with the ideas propounded in Geshundheit, you will not be able to ignore them. Patch believes doctors must empathise with their patients and share in their experiences. It is only then that we can hope to limit the spread of medical litigation and restore the traditional trusting relationship between patient and doctor.

There are many memorable quotes in this book. However, the one I like the best concerns patients and how to be an ideal patient:

"Try to care for your caregivers, no matter how poorly other health care professionals may have treated you in the past. Once you choose a caregiver, enter the relationship full of trust, excitement, openness and friendliness. There is a lot of pain in the healing arts. Many healers feel burned out, frustrated, angry and depressed. So act as if you wanted to enrich their day ...... Be a patient patient".-John Mayberry, Editor 